\title{
Gerard Manley Hopkins and Walter Pater: The Labyrinths of Transience
}

\author{
Mirko Starčević
}

\begin{abstract}
Transience forming life's very essence left an indelible mark on the creative explorations of Gerard Manley Hopkins and Walter Pater. The permanently indeterminable presence of mutability made both of them face the umbrous and unknowable aspect of death, thus revealing unto them the task of determining the role of art in life ruled by ceaseless corrosion. Pater accepts the flux of mutability as the primary particle in the revelatory act of the authentic creative experience. The power of that which is frolicsome in art augments the constitution of life's essence submerged in the unsettled condition of fate. Hopkins the priest particularly in his theoretic excursions recognizes in art itself only an approximate value to the timeless grandeur of God's ubiquity. His poetry, however, presents a dissimilar narrative. The poetic image that Hopkins forges corresponds to the mode of exposed individuality of the Romantic spirit, which Pater perceives as the harmony of strangeness and beauty. During Hopkins's student days at Oxford, Pater's relationship to the young poet was not confined to coaching only. Much of their time they spent in conversation, meditating upon the essential principles of artistic expression. Pater influenced Hopkins greatly and contributed impressively to the discipline of his poetic heart. Traces of this companionship do not find the path to Hopkins' religious ruminations; they announce their own existence, although very subtly, upon the individual levels of Hopkins' poetic yearnings.
\end{abstract}

Key words: Hopkins, Pater, Romanticism, Flux, Beauty 
I.

The Trinity Term of 1866 Gerard Manley Hopkins began by moving into new lodgings at $18 \mathrm{New}$ Inn Hall Street. That spring was unseasonably chill-stricken and the otherwise flamboyantly verdant hues of greenery shuddered withdrawn under the grim layer of frozen crystals. It was at that time when Hopkins started composing his new journal. In his first entry dated 2 May 1866, he in passing alludes to an early evening walk he had shared with Walter H. Pater, a Fellow of Brasenose, on 30 April: "Coaching with W.H. Pater this term ... Fine evening bitterly cold. 'Bleak-faced Neology in cap and gown': no cap and gown but very bleak" (Journal 133). This terse observation unmasks a dense layer of the persona that was Walter Pater in the eyes of many an Oxonian.

The true nature of Hopkins and Pater's relationship to this very day lingers shrouded in the veil of mystery. In a similar vein, a number of contending views have been expressed as to how Hopkins first chanced upon Pater and his work. Hopkins may have first become acquainted with Pater's work, as Robert Bernard Martin suggests (131), through Samuel R. Brooke's account of his having attended a gathering of the Old Mortality Society, an academic group where Pater gave a reading of one of his essays on the affiliation of morality and beauty - or rather of beauty as the deciding measure of what can be conjectured as being moral - in a work of art, an essay which Brooke, whom Hopkins met in May 1863, in his diary decries as "the most thoroughly infidel production" of "eminently selfish principles" (qtd. in Monsman, "Old Mortality in Oxford" 371). The fact that Hopkins had by at least 1864 become cognizant of Pater's dilating renown may be corroborated by a diary entry that Reverend Henry Liddon, Hopkins' first confessor, made on March 7 1864: "Walk with Hopkins of Balliol. He told me about Pater's paper on Fichte's 'Ideal Student at the Old Mortality Club,' in which he denied the immortality of the Soul" (qtd. in Monsman Walter Pater 31), and, furthermore, by another entry produced mere four days later: "Hopkins mentioned to [me] the project of an essay club, of a church character, a set-off against the Old Mortality" (31). The essay club here invoked by Liddon, its first president, was to be named the Hexameron. Its principal ambition was to scale down, in their members' eyes, the nefarious influence of the unbridled peccancy promulgated by the Old Mortality Society.

In contrast, David Anthony Downes propounds that it was Benjamin Jowett, a Fellow of Balliol since 1832 and Tutor since 1840, who first introduced or at least made Hopkins conscious of Pater's stature in Oxford, and later also communicated to him that he was to undergo coaching for the Greats exams in 1867 under the tutorship of Walter Pater (22). This was still the time of Jowett's deep fondness for Pater, which he had most markedly intimated during his tutorship of 
Pater by envisioning the strength of Pater's mind to climb upwards to reach "great eminence" (25). Jowett under the swell of his personal deeply held Broad Church attitudes identified Pater - whose incipient enthrallment by "the relative spirit" (28) of looking at phenomena in accordance with the essence that they purvey to the onlooker was becoming less attenuated - as a vehicle for steering Hopkins away from the shores of Puseyism to a certain degree and more so Newmanism. ${ }^{1}$

Hopkins' antonomastic reference to Pater as "bleak-faced Neology, in cap and gown" stems forth from Charles Turner's sonnet "A Dream," published in the volume Sonnets (1864), wherein he takes the not inconsiderable liberty of swiping down the skepsis of the latitudinarian ethos. Neology was a term coined in relation to the intemperate climates of rationalism in German theology and philosophy steeped in highly acquiescent exegetical and doctrinal readings of the Bible. Pater made his name as one of the most formidable exponents of German idealism in Oxford, which won him the Fellowship of Brasenose College, but also a legion of peers and students maligning him for it, with Hopkins, introducing him to the dawning pages of his journal as a proponent of enlightened theology, unequivocally being one of them. Not many days later Hopkins proceeds to underscore his discordance with Pater in yet another note: "A little rain and at evening and night hard rain.-Pater talking two hours against Xtianity" (Journal 138). The discord related to here by Hopkins in all probability has its provenience in Pater's conception of the miraculous. The inimitable semblance of the "penetrative suggestion of life" Pater locates in "the austere truths of human nature" (Renaissance 43). The strict accord of one's existence is to be sought after in the waning light of one's life, in the light not residing within the impassive prospect of the afterlife but flowering upon the bed of the unvanquishable eternity of the momentary clarity of perception.

From the Christian perspective, it is a not mildly unorthodox judgement of the miraculous. Pater does not in its entirety divorce it from the Christian creed, but removing an aspect of blankness from the unseen, he by proceeding to define that which is miraculous as not being forged by Christianity declares that Christianity itself is contained within the miraculous. In his later and yet unpublished manuscripts, Pater acknowledges a huge societal, communal, and even artistic value of Christianity. Even more emphatically does he utter the overpowering urgency of magnifying and exploring the extremities of this brief candle-like existence with "art and song" (Renaissance 120), for we are given an interval and "then our place knows us no more" (120). The brevity of an interval might breeze in as a sombre prospect, a pilgrim's quest of the manifold perils for the flame with-in called by Pater, according

1 Pater's beliefs and ever-growing aestheticism unwilling to conform to the prevailing atmosphere of the era would later grow intolerable to Jowett and impose severe strain on their personal and professional relationship. (Higgins, "Essaying 'W.H. Pater Esq.' 2) 
to Brooke, "Subjective Immortality" (qtd. in Monsman Walter Pater 30). The indomitable cord of Immortality is weaved in the fond remembrances friends keep retrieving of the one whose life has expired. The opposed substance to this form of Immortality is Annihilation, a hollow ground of being forgotten. Brooke dissents resoundingly from the proposed distinction. He perceives subjective immortality as being indistinguishable from Annihilation because friends also die and with them memories, so that Pater's vision of Immortality sooner rather than later melts into nothingness and proves for Brooke as elusive as wind's puzzling movements (3031). But ensconced within this duality is the image of a self-cultured aesthete, a scholar of hued perceptions, Wallace Stevens' "scholar of one candle" ("The Auroras of Autumn" 142), frightened and impacted not with the eminence of memory merely. The brief interval of effulgence likewise shines upon the Primal Scene and "empirical context of history"(Monsman, Walter Pater 33), wherein cultivated by the abiding impulses of beauty one becomes a progenitor of the age.

II.

Omnipresent in Pater's aesthetic propensities lingers Ruskin's spirit. In partial and relative conjunction to his central dictum developed in Modern Painters III that "to see clearly is poetry, prophecy, and religion all in one" (268), Pater in the preface to his seminal work Studies in the History of the Renaissance adumbrates the contours of the question that was to form the crux of his critical ruminations: "What is this song or picture, this engaging personality presented in life or in a book, to me?" (3)

Also under the spell of the "Ruskinese point of view" (Further Letters of GMH 202), Hopkins' intellectual debt to Ruskin first acquires a cognizable form in a letter sent to William Baillie, a fellow Balliol student, in which he summarily yet artfully documents the visionary fruits of one of the sketching trips he undertook with his brother Arthur:

I think I have told you that I have particular periods of admiration for particular things in Nature; for a certain time I am astonished at the beauty of a tree, shape, effect, etc. then when the passion, so to speak, has subsided, it is consigned to my treasury of explored beauty, and acknowledged with admiration and interest ever after, while something new takes its place in my enthusiasm. (202)

The instressed shape, say, of a leaf affords the discerning onlooker an experience of a distinctive light of its selfhood, its leafness, or singular effect residing outside the intellect. In 1863 the skeleton of these cogitations represented mere fledglings of what would later grow into an impacted and particularized relief of Hopkins' poetic 
excursions. Ruskin, who maintains that seeing precedes thought and that the Seers in contrast to the Thinkers "are wholly the greater race" (Modern Painters III 268), is unmistakably present in the ideational surroundings knitted by Hopkins. The onlooker's task is to record rather than reinvent Nature (White 75) and at the same time withstand the yen of projecting life upon it. Poets who prove not impervious to the impulse of adopting Nature to the projecting principle, called by Ruskin pathetic fallacy, fall in Ruskin's estimation within the category of Perceptive or Reflective poets who "feel strongly, think weakly, and see untruly" (Modern Painters III 164) as opposed to Creative poets who "feel strongly, think strongly, and see truly" (164). Ruskin regards the Romantic legacy of the "renewed encounters with the visible nature" (Bloom xii) as regressive defacement of "the pure physical nature" (Bloom xv).

In other words, psychologizing enquiries miserly exhaust the absolute essence of natural data. Citing two verses from Charles Kingsley's poem in Alton Locke: "They rowed her in across the foam / The cruel, crawling foam," Ruskin rather acerbically adds that "the foam is not cruel neither does it crawl" (Modern Painters III 160). Having a temperamental bias to over-mystify and smog facts, emotions must, for this reason, be guarded against. At this stage, it is crucial to bring up the notion of feeling, for being moved rather than overwhelmed by feeling, Ruskin regards as a nonpareil in terms of poetic potency. Dante according to Ruskin's norm stands as a strong poet unbent by the swirl of emotions, a poet who possesses a steadfast "centre of reflection and knowledge ... and watches the feeling, as it were, from afar off" (164). Dante accepts the despotism of Nature without trying to rescind the primal balance. A weaker poet, however, exhibits intoxication with the self and is incapable of inhibiting the "overcharged expression" (165) generated by the fawning infatuations with the Natural law.

Pater, an ambivalent but undeniable disciple of Ruskin, swerves away from his precursor in one key respect; he does concede Ruskin the precept that to regard an object as it is in itself demands not small a measure of nobleness and instinctive modesty. Nevertheless, he does act out a fundamental revisionary shift to Ruskin's principle of singular unity by stating that in order to see the object in its singularity one must first become acquainted with "one's own impression as it really is, to discriminate it, to realise it distinctly" (Renaissance 3). Pater is by no means a purveyor of the doctrine of over-clouding and enwrapping physical facts inside the mechanisms of psychological reductionisms. Where Pater writes of the significance of sensory acuity, he does not endorse the tyranny of the senses; on the contrary, he addresses those special and privileged moments of intellectual clarity, "pathetic fallacies raised to triumphs of perception" (Bloom xiii), which Wordsworth calls the "visionary gleam" "Ode" 56). Wordsworth, Nature's own abandoned son, craves not the return to its pitiless bosom; such return would entail surrender of imaginative vigour to the antithetical flux of naturalized ambition. The visionary gleam - an appearance of wild temporality 
- affords the poet an insight, of which he is terrified, for the child should go back only as the Father or "the Child [who] is Father to the Man," because "words are wild" (Hopkins, "A Trio of Triolets" 27), and the returning poet can survive Nature's dehumanizing lure only if willing or capable of lending myth of "human thought" (Pater, "Wordsworth" 131) to Nature and for that one instant of clear prophecy face the prospect of the darkening gleam. Blake informs us that "the Imagination is not a State: it is the Human Existence itself / Affection or Love becomes a State, when divided from the Imagination" ("Milton: A Poem in 2 Books, Book the Second" 32-33). In the "Postscript" to Appreciations, Pater defines an imaginative leap of Romantic poetry as strangeness added to beauty (211), naming Sir Walter Scott and Heathcliff among others as the spirits of "strange adventure" (209) and hence the paradigmatic representatives of the Romantic temper. Such a temper is further pronounced in the event of the desire of beauty being complemented by curiosity. That is to say, love of beauty entwined with an intellectually disinterested thirst for knowledge renders fruitful the quest for the strange union of "unlikely elements"(212).

The prospect of marriage between seeming antagonisms profoundly moved Hopkins. He intensely channelled his mental energy first into producing a theoretical examination upon the vital individualities of keen observation which can if only within a twinkling spot of time espy the thisness of the observed object, and then setting the revelatory fragments of this principled study into his creative outpourings. Despite Hopkins' early protestations against Pater and a chasm between their respective outlooks not so much on religious life as on the absolutist decrees of religion per se, Hopkins never gainsaid the immense impact Pater's thought had on his speculative and poetic reflections, and many a time made those kindred offshoots visible to a keen eye. This can also be attested to by a more conspicuously benevolent fashion Hopkins granted for his relationship with Pater to assume in the years following his departure from Oxford. In 1878, eleven years after taking his degree in Oxford, Hopkins, a Jesuit priest now, returns for the first time "except once for three quarters of an hour" to the city of dreaming spires (Correspondence of GMH and RWD 20), and while at St. Aloysius' sends a letter to his mother informing her that he "[dined] with the Paters" (Further Letters of GMH 151). Two years later still with fondness in a letter to Baillie he recalls this event and writes that during that 1878 stay in Oxford Pater was "one of the men I saw most of" (246).

\section{III.}

We have determined early on that Hopkins' initial impression of Pater might have been unduly volatile while our last remarks imply a major shift in Hopkins' disposition towards Pater. Since the inklings of personal cordiality between the 
two of them first took shape within the boundaries of intellectual life, we will seek to expound upon the covert aspects of Pater's ascendancy inside the maze of Hopkins' - albeit metaphysical - Weltanschauung. Along with some of the essays Hopkins penned at Oxford, his critical perusal of Ruskin deliberated upon in light of the brief analysis of Pater's intellectual agon with Ruskin that we have already carried out will help us gauge the extent of influence the Brasenose don did have on the Jesuit poet.

Verbal sketches that Hopkins adopts in his writings he traces in great preponderance in Ruskin's Elements of Drawing; stems "send off a wild branch," "branches share in one great fountain-like impusle," and "boughs spring irregularly and at various angles ... stoop less and less as they near top of the tree" (93). These verbal charts are conceived in order to outflank a periphrastic silhouette of a natural form so as to ingress the form and its haecceity, the intellect's individuating perception of a singular form. Ruskin calls such order of perception signalement, a quest for "the vital truth ... of every natural form" (92). Hopkins gradually became aware that progression as a trait of painting was not particularly valued in the Victorian era, and the operative scheme of expression he commenced assuming was more and more confined to highly idiosyncratic and minutely detailed scrutiny of the natural phenomena. The chase after thisness of "every nut-tree, and apple-tree, and higher bit of hedge" (86) turns for Hopkins into the very air that he heartily longs for to endlessly breathe. On 12 December 1872, during his three-year stay at the Jesuit seminary at Stonyhurst studying philosophy, Hopkins went for a walk on the fells with a not infrequent walking companion Herbert Lucas SJ. In his journal for that day, he makes this note:

Ground sheeted with taut tattered streaks of crisp gritty snow. Green-white tufts of long bleached grass like heads of hair or the crowns of heads of hair, each a whorl of slender curves, one tuft taking up another - however these I might have noticed any day. I saw the inscape though freshly, as if my eye were still growing, though with a companion the eye and the ear are for the most part shut and instress cannot come. (Journal 228)

Hopkins confesses that inscape of the kaleidoscopically tousled leaves of grass does for an instant reveal itself, yet instress refuses the courtship of more than one set of eyes. It might be helpful to fortify the point that instress is always "received from ... [the] inscape," (263) meaning that instress embodies the act of seeing as much as the event of being seen. The progressive form of the verb to grow, denoting the operating process of instress buttressing the foundation of inscape, reflects a telling gesture of having to be intently open unto the possibility of uncovering inscape in that acutely epihpanic spot of time that is instress. Since the vision of inscape 
is predicated upon the sonorous bond with instress, it is not "inscape," as Brian Willems contends, but more so instress where "God himself" (5) inheres, as is highlighted by Hopkins, who further clarifies in "Parmenides" that "all things are upheld by instress and are meaningless without it" (127). For inscape to become visible through the energy of instress it must be called upon in solitude. Declaring that "all the world is full of inscape," Hopkins discerns it even in "random clods and broken heaps of snow" (Journal 230), but early spring is when "the swelling buds" take "the spraying of trees" (205) to a perfect pitch of mind and nature, as Miller propounds, to ensure "for the stem of stress to leap out and bear things over to the mind" (294).

The Ruskinese standard of variety in oneness haunts Hopkins. Having abandoned the dream of becoming a professional painter, he began concentrating visual memoranda verbally, which he advances theoretically in "Notes on Greek Philosophy." He articulates the motifs on the relational anomalies of words, locating an indwelling spirit of multiple connotative shapes in words possessed through "a passion or prepossession or enthusiasm" (306). The texture and huskiness of words is tested against its rhyming potential. These relational patterns in words manifest themselves in the tripartite nomenclature of prepossessing feeling, definition or abstraction, and its application or, in Hopkins' phrasing, "extension" (306). Regardless of the prepossession subsuming a word's connotative aspect and extension being "a thing meant" (306) by a word, it is a word's abstraction met in expression which receives its lexical corporealness. Only expression is causally responsible for the "uttering of the idea in the mind" (307), and beyond even this underlying expressiveness of what really constitutes a word rest the veritable image, its visible and audible mark thronged with "refined energy" (307), and the conception of the idea. Energy released externalizes itself transitionally and contemplatively. The former mirrors the successive exhibition of "thought and sensation" undertaken actively in criticism or passively in reading, while the latter pleasurably wades into the mind which then in contemplation "dwells upon, enjoys, [that] single thought" (307). As Hopkins contends, these two energies are not mutually exclusive and can subsist simultaneously in art as even "the synthesis of succession" can - despite its focus on the totality of intermediacy - help securing the contemplative thrill of the parts bound in unity. In his work, however, contemplative supersedes transitional energy, for only contemplation adequately reflects the distinction between "the whole and the parts, the parts and the whole" (307), and it is in this distinctive possibility of contemplative energy where the real "sense of unity" resides (307). The vital truth of the word brought into being by virtue of expression, it takes a connotative and effortful leap back into the prepossessing flush for the oneness of the mind to seize the unity of truth. Prepossession under the creative aegis of Hopkins flouts mere impressionistic suggestiveness of words, seeking rather "an intellectual attraction for very sharp and pure dialectic or, in other words, hard and telling art-forms" (308). 
Paul Mariani identifies Pater's aesthetic sentiment which he reduces to a level of overly pliant and self-indulgent "bifurcated and unwound" (67) layers of perception as inconsonant with Hopkins' pattern of sturdy and sovereign makeup of inscape. Miller makes even more resolute a comment that Hopkins in his youth was caught within "the prison of Paterian phenomenalism" (275), out of which he desperately struggled to escape. That Hopkins' aversion to subjectivism with the passage of time did grow in intensity can hardly be invalidated, yet the character of relativism Pater espoused has to be revisited at this point as this will assuage the path of determining a more genuine sense of Hopkins' contact with Pater's epistemology and the effect it had on both his poetic and religious mood.

In The Child in the House, Pater's autobiographical portrait, Florian Deleal, whose reveries constitute the elemental frame of this short account and hold many a key to the proper understanding of Pater's visionary aestheticism, is ruled by a tender and melancholy state of mind in constant desire of beauty which itself can coexist only with "the fear of death" inasmuch as "the fear of death [is] intensified by the desire of beauty" (11). The vast expanse of nothingness which death promises first engulfs Florian's highly impressionable senses during his summer ramble in a "fair churchyard," where "a dark space on the brilliant grass" (11), an open grave where some child will rest eternally, bestirs his soul, inducing his vernal elation of life to gain knowledge of "the physical horror of death" (11) for the first time. Desiring to know what the intensity of an expiring life might feel like, he meditates "how the last impressions of eye and ear might happen to him, how they would find him" (11). The ceaseless evanescence of one's existence, for "the fear of death [comes] upon [Pater] early" (23), accentuate his conviction that life is drained in the amorphous flux of vibrant and relentless continuity. Faced with life's transience, increasing the susceptibility of the senses "in dept and variety" (Renaissance 4) should never be hesitated against. For such increase and enrichment in the nuanced substance of that brief interval to arrive into being, an aesthetic and nourished training of one's mind is required. Sensation, "response to perception" (Bloom viii), demands an ascetic delving into the matter or form so as to procure the individuating sonority of an object, the exclusivity of which is incumbent upon the observer's nurtured openness to be "moved by the presence of beautiful objects (4). This view can easily get conflated with the type of base hedonism of the perilous delights many in Oxford imputed to Pater's critical undertakings. Pater is often cited as saying that he would have liked for the detractors to stop calling him a hedonist; it "[produces] such a bad effect on the minds of those who don't know Greek" (qtd. in Thomas 47). In his review of Oscar Wilde's The Picture of Dorian Gray, Pater extols the novel's exceptional aesthetic resilience, yet Dorian and Lord Henry, two of its main protagonists, both "lose too much in life" (265) to evade the seductions of ill-begotten Epicureanism, a province of crass 
cynicism and scarred sensibilities that Pater sets in opposition to the virtuous and creatively charged life of Basil Hallward, whom Pater for these very reasons acclaims as a paragon of authentic "Epicurean economy" (265).

Any true prophet of Epicureanism was habitually quite acrimoniously discredited as a hedonist, a term which had through much misuse acquired a very unsavoury reputation as a system of thought advocating the low-minded and puerile worship of pleasure for pleasure's sake. Understanding that the real sense of hedonism was lost and vulgarized within the dusts of history by the institutions of the "righteous" cause, Pater, who had felt the oppressive scourge of such naïve vilifications, sought to offer a clear distinction between vulgar hedonism and Epicureanism. Unlike hedonism, Epicureanism had at least in the minds of the learned few retained a modicum of its unadulterated significance, "designating actual schools of thought and traditions of philosophic thought" (Shuter 48). Hedonism, originally very much inseverable from Epicureanism, deteriorated into a word of "large and vague comprehension" ("Marius the Epicurean" 124) no longer able to epitomize the ethos of Cyrenaic and Epicurean pleasure, the custodians of "insight" and "fullness of life" (125). Pater felt impelled much to his chagrin to sever the ties of hedonism and Epicureanism to render the latter impervious to the potentially analogous doctrinal reductionism and detritus of wilful ignorance the former had been subjected to:

A true Epicureanism aims at a complete though harmonious development of man's entire organism. To lose the moral sense therefore, for instance, of the sense of sin and righteousness ... is to lose, or lower, organization, to become less complex, to pass from a higher to a lower degree of development. ("A Novel by Mr. Oscar Wilde" 264)

A degree of harmonious development hinges upon the disciplined variety of both the heart and mind. His Epicurean discipline Pater mingles with Cyrenaic arching yet brief moments echoing within the exalted privacy of one's sensations: "Art comes to you proposing frankly to give nothing but the highest quality to your moments as they pass, and simply for those moments' sake" (Renaissance 121). To a greater extent, however, Pater dwells on facilitating the passage into the domain of katastemic pleasure, a static pleasure of tranquility or ataraxia, elicited into existence by the kinetic experience of joy. Seeing the fleeting aerial dance of a falling leaf kinetically can energize the mind to pass through joy or wonder, whereas having seen a subliminal vision produces the static and somewhat subtler yet less ephemeral a pleasure of comfort. Static pleasure could mislead one into thinking that the pleasure thus attained stands exposed to the gradually tougher ebbing tides of the intensity of sensation. If the heart and mind are impressible and grant to be 
purged of intellectual dross, the accumulated impulses of introspective bliss may appear dormant, but they in concert with each impulse freshly forged within the soul augment the varied experience of pleasure. Kinetic pleasure arises in the process of removing the pain; once this has been achieved, katastemic pleasure is formed. The removal of pain, therefore, makes place for the experience of contentment. Pater, suffering a life-long ontological anxiety, endlessly yearns for the epiphanic moments in the swirling midst of the kinetic and katastemic duality, wherein the imaginative pleasure burning intensely along the bedimming pain gradually morphs into an amicable calm of equanimity. A seasoned eye can aim for the rarefied particularity of being present in an apotropaic encounter with death, one's unrelenting shadowy companion. Upon the exile of pain or anxiety, death becomes absent, although it still remains present in its absence as a lingering suggestion or possibility, so that ataraxia is never entirely unrestrained (O'Keefe 117-123). Pater understood that the restoring fruits of high pleasure can only be watered by the tears of life's transience, making him thirst even more for those brief intimations of immortality.

In an essay "The Probable Future of Metaphysics," Hopkins devises a system flowing against the tide of "the prevalent philosophy of continuity or flux" (120), by many regarded as being the favoured child of Pater's aesthetic theory:

One sees that the ideas so rife now of a continuity without fixed points, not to say saltus or breaks, of development in one chain of necessity, of species having no absolute types and only accidentally fixed, all this is a philosophy of flux opposed to Platonism and can call out nothing but Platonism against it. (120)

Miller, for instance, analyzes Hopkins' conception of diatonic beauty as a supreme sign of the poet's "rejection of the Paterian philosophy of flux" (278). It is in his undergraduate essay "On the Signs of Health and Decay in the Arts" that Hopkins first presents his theory on the two discrepant spheres of beauty. To examine the veracity of Miller's assertion, we must first illuminate the rigid distinction Hopkins offers between two types of beauty. In the "science of aesthetics" ("Signs and Health" 75), as Hopkins refers to his theoretical model, he formulates a method for envisaging the true nature of beauty. The highest standard of beauty he locates in proportion, which communicates the character of beauty either by the strand of continuance or the tilt of interval. The latter Hopkins held in preference over the former. Beauty disclosed intervallary, quantitatively, or parallelistically is diatonic beauty, while beauty conveyed gradually or qualitatively he names chromatic.

Miller's assertion hints at Pater's rather servile reliance on the "shapeless slum" (278) of the flux, wherefrom spontaneous, non-predetermined, and evolutionary lawlessness sets up a patterning arrangement hostile to the tabulating order of rhyme. Against Miller we can read Wolfgang Iser, who astutely points out that 
impression for Pater has the ability to lower the "barrier between art and life" (36) or what Hart Crane in the proem "To Brooklyn Bridge" calls the might of the "unfractioned idiom" in the awoken impressions to "condense eternity" (34-35). Iser adds that for Pater impression in its primordial solidity alone discharges an interval from "the 'permanent flux' and enables it to defy time by freezing the transient into a permanent image" (37).

Pater's askesis typifies a regulative gathering of order in time's unbroken wave, rephrasing amorphous figurations and their "restless iteration" (Stevens, "The Place of the Solitaries" 11) into the parallel stratum of the highly punctuated and minutely measured decree of rhyme. In a similar vein, Hopkins shapes his rhyming patterns as a panacea against the splintering vacuity of the flux. The rhyming undulations subsume phenomena which are alike in their unlikeness and unlike in their alikeness.

Pater was, not unlike Hopkins, profoundly scraped by the potential meaninglessness of mutability, so it is not incredulous that the capricious fluidity in Pater galvanized the ever-lingering propositions and flames of faith. Moments when the Muse of rooted revelation shrouded herself in silence made him re-turn "again and again toward the solemnities of faith" (Millhauser 216). Owing to Pater's multifaceted and warring notions on religious faith, Hopkins' ties to him were, as a result, even more elaborately interlaced. At the age of 18 , he seriously wrestled with the idea of taking religious orders in the Anglican Church; so prominently were Pater's thoughts focused on devotion that he deemed Lancelot Andrewes' Manual of Private Devotions a book of such gravity that any person should read it. In all probability, such reasoning led him to present the book as a birthday gift to his friend John Rainier McQueen. (Thomas 22)

Church walls which Pater frequented insatiably allayed his existential trepidations; the tall embrace of church spires and Gothic arches extended him solace. Confronting the colossal and dehumanizing societal vicissitudes of the modern world, Pater exhorts his contemporaries to "rearrange the details of modern life, so to reflect it, that it may satisfy the spirit" (Renaissance 116). The overpowering sense of modern life that nothing else is there to be gained knowledge in steadied Pater in his missionary work to reiterate the need to see the spirit of the age as an untrammelled entity, as Higgins contends, "anterior to morality, myth, and religion" ("A "Thousand Solaces" 190). Pace Coleridge, who believed that in the event of rejecting the element of "the supernatural, the spiritual element in life will evaporate also" ("Coleridge's Writings" 448), Pater perceives religion as an outgrowth of the primal spirit of being and not its originating agent, toiling profusely to reanimate and attune that spirit to its moral, mythological, and religious undertones to make it withstand the surging stream of scientific determinism. Artistic synthesis in union with the inspired atoms of religious emprise is effected when the mind 
proves susceptible to the ever-rejuvenating ecstasy of transporting experience partaking in the creation of "moral "impressions" (Higgins, "A 'Thousand Solaces" 195), thus, according to Pater, keeping life from being "a mere grasping" (qtd. in Higgins 200). Much like artistic, religious sentiment winnows its way outwardly, and settles upon the arable plains of higher reality with "creativity, communality, and consolation" (191); for Pater, the three vital benedictions of religion. Although in the eyes of many who are devout, faith produces hope everlasting, Pater seeks no such gratification. The uncertainty of the flux can neither be overturned nor quelled. He is not willing to shade its real hazard, rather he embraces it as part and parcel of the facticity of human existence. In his view, authentic religious belief, an offspring of doubtful faith, but faith nonetheless, comes not by means of an original vision of revelation; on the contrary, such a vision being out of reach, a cure for belatedness may be procured only in the unique re-creation of the impulse which points amidst the flux to the momentary yet lifting salvation of life's sacred value. Prescriptive institutionalization and dogmatism is far removed from the essential cheerfulness contained in the disrupted and divided balance of faith. Faith not frosted upon the throne of absolute authority could only thaw on the wings of a concession that "there are aspects of the religious character which have an artistic worth distinct from their religious import" ("Coleridge's Writings" 448-49), for only in this manner does faith commanded by "longing, a chastened temper, spiritual joy" (449) not exhaust its innumerable modes of appearance.

Iser emphasizes that Pater's scepticism can be valued as either "negative (rejecting the norms of the absolute spirit) [or] positive (bringing to light the undefined and undefinable)" (17). This contrast could easily give rise to an erroneous portrayal of Pater's intuitive criticism as an apologia for radical egalitarianism, which Pater being aware of the metaphysical and despotic undercurrents present in it explicitly renounces:

But a taste for metaphysics may be one of those things which we must renounce, if we mean to mould our lives to artistic perfection. Philosophy serves culture, not by the fancied gift of absolute or transcendental knowledge, but by suggesting questions which help one to detect the passion, and strangeness, and dramatic contrasts of life. (Renaissance 116)

The only semblance of permanence held in patent reverence by Pater is "a standard of taste which genius confesses" (98). Genius soundly tunes the "mortal truths of perception and sensation" (Bloom xxx) to the cultured and lofty discipline of noticing the radiant thingness of a thing not "in action but contemplation-being as distinct from doing," of opening life unto "the principle of all higher morality" ("Wordsworth" 139). It is not the solipsism of vulgar subjectivism 
masking an idea within form and therefore life; his longings range from witnessing the unconcealedness of a beautiful idea to an inclusive and reciprocal sense of communal but agonistic kinship of ideas; an idea true unto its own reality, and then only to the principles of subjectifying and objectifying ratios.

Whereas Pater's philosophical, aesthetic, and creative wanderings rise unapologetically in consonance with one another, Hopkins' exertions to reach the highlands of mental congruence within his theoretical, theological, and creative undertakings are a matter of often tortuous forethoughtfulness; yet in a spirit of so much inquisitive ingenuity such unity of thought upon being achieved cannot be divested of brazenly unique splendour. In "The Origin of Our Moral Ideas," Hopkins writes that "all thought is of course in a sense an effort of unity" (83). Unity is disrupted by the flux, and in the world where everything is "seared with trade; bleared, smeared with toil" ("God's Grandeur" 6), the likelihood of salvaging unity abides with inscape of God's indwelling presence in all things living, in "designs of Greek vases, and lyres, the cone upon Indian shawls, the honeysuckle moulding, the fleur-de-lys" (Hopkins, "The Probable Future of Metaphysics"120). The constellated structure of unity opens up the room for the character of thought where "the highest consistency is the highest morality ("The Origin of our Moral Ideas" 83). In morality the movement is always within a fixed point, but in art the motion transcends the point centripetally to attain a "permanence of law, likeness, but also, with it, difference, variety, contrast" (83). Neither Pater nor Hopkins shy away from expressing hopes in the re-emerging nature of timeless values in works of art with the difference being that Hopkins desires for these values to restore the realm of metaphysics, while Pater sees their task in enhancing the recovery from the metaphysical mould. Hopkins' general take on the timelessness of spirit is obviously steeped in a highly religious mood, so that the main recourse to certify values of this kind rests in the inauguration of an externally-imposed absolute law of order. We have already alluded to Hopkins' non-linear approach to the formation of the syntheses of artistic and moral dispositions. As the sense of morality alone cannot inject the substratal impulse essential for artistic creation, Hopkins holds the goal of achieving high moral pleasure through art in great regard. Not only does he crave for beauty because it is good, he also, like Pater, although with a larger degree of moderation hankers after goodness because it is beautiful, in which case goodness is subsumed as one of the primary facets constituting beauty.

Hopkins oftentimes assumes a banausic tone in his comments on poetry, stating that "the clearest and most disinterested appreciation of beauty comes of education" ("The Origin of our Moral Ideas" 218). In "Plato's View on the Connection of Art and Education," he makes no effort to disavow Plato's banishment of a poet from the Republic, where only "the more austere and less delightful poet" (223) is allowed to interact with the citizens. He was disheartened at the prospect 
of upsetting the balance between goodness and beauty, of possibly tilting the moral compass inordinately to the vicinity of beauty per se, which could spawn his already piercing sensitivity to beauty to a riotous gallop of the daringly-inflamed senses, to a life of indulgence his religious constancy could not brook.

Art in the Paterian sense comes to be, so to speak, one of the enlargements of life. Hopkins feared that the enlargement of life in art if relished excessively could become larger than life of devotion itself, thus displacing “the' end from life” (Iser 35), which Hopkins searched for in the unremitting service to God. Daimonic boundaries of poetry are treacherous and hardly perceptible and the defensive mechanisms Hopkins employed against the frenzy of poetic vocation were manifold. They were made plain in the steely and self-flagellating themes ruling over Hopkins' quotidian practices as a priest. The singular credence of God's wondrous emanation the poet identifies in the unmitigated contact of his senses with the incarnate ripeness and purity of God's glory:

The world is charged with the Grandeur of God,

It will flame out like shining from shook foil,

It gathers to a greatness, like the ooze of oil

Crushed. Why do men then now not reck his rod? (“God's Grandeur”1-4)

The charged reality of experience bespeaking the inviolate presence of the divine body could best be sustained via an undeviating contact with God through the vibrating senses. Mystery of man's communion with God Hopkins describes as "incomprehensible certainty" (The Letters of GMH to Robert Bridges 187). He reprimands Bridges for seeing mystery crucially in different terms: "You mean an interesting uncertainty: the uncertainty ceasing interest ceases also" (187). The unknown entity mirrored in the unspent energy of Nature's fruits which "the mind reaches and still feels to be behind" (187) can be entered into by the non-complacent agency of the spirit. The signifying particle of God within the poet's soul markedly took shape in the idiosyncratic cosmos of Hopkins' language and sprung rhythm, of which he wrote to Bridges: "No doubt my poetry errs on the side of oddness ... This vice I cannot have escaped" (66). This oddness escaped not the sharp eye of his Jesuit colleagues who often viewed him as a quirky brother in Christ. Recommending Hopkins for a post as Fellow in Classics and Professor of Greek and Latin Literature at the University College in Dublin, George Porter, an English assistant to the Jesuits' Superior General in Rome, salted the endorsement with a caustic remark that Hopkins is "clever, well-trained, teaches well but has never succeeded well: his mind runs in eccentric ways" (qtd. in Martin 362). Oddness of character and poetic word is reminiscent of the parallelism of beauty and strangeness Pater marked as the stamp of the Romantic spirit: 
There are the born romanticists, who start with an original, untried matter, still in fusion; who conceive this vividly, and hold by it as the essence of their work; who, by the very vividness and heat of their conception, purge away, sooner or later, all that is not organically appropriate to it ("Postscript" 218).

Although in hacking away at the raw materiality of the idea charged with the caritas of God Hopkins notices a deliberate destruction of nature, the purging away of the redundant layers to gain sight of the clear aspect of form - contained within the "marked parallelism" (Hopkins, "Poetic Diction" 84) of the opposed forces to which poetry aspires - Hopkins estimates as the cardinal imaginative measure against the blunting clasp of indifferentism. The Spiritual Exercises of Ignatius Loyola depicting the victuals upon which the souls are sustained, indifferentism is one of the aims which a devoted heart and mind should seek to achieve during the Exercises:

One must grow cold to all things: love of friends, country, parents; particular interests; kinds of learning ... In fine the ideal put forward is that of a soldier held by no tie of affection, burthened by no choice or fancy, utterly detached from all natural desire, having no preference ... Indifferentism entails such an absorption in the final end ... that it engenders necessarily an attitude of aloofness, coldness and ennui ... Art and dreams have no value in themselves, and must be bartered for whatever helps piety. (Barrett 79-80)

The strict code of the Exercises could prove detrimental to "a temperament predisposed to melancholia" (White 187); melancholia is evident in the way Hopkins - despite being in a community generally quite supportive of his poetic endeavours - reacts to his poem "The Wreck of the Deutschland" being rejected by the Month. In one of the letters to his mother, he tells her: "About the Deutschland sigh no more, I am glad now it has not appeared" (Letters to Patmore 141). In spite of the outgoing tides, the excited and over-believing oddness of his poetic spirit is not un-selved. Julia F. Saville highlights a spiralled trajectory in Hopkins' instressing of "the common nature or inscape" (98). The poet postpones the passing of the momentary interval by "the act of stalling" (98) and by virtue of the concentration of the impressed impulses the pleasure thus heightened becomes "indistinguishable from the guilt of seeing too much" (98).

Rare moments of freedom from reticence in Hopkins prove tantamount to the temporary abandonment of the real in favour of the tentative encounter with the sublime, bypsos, or loftiness personified in nature's intimidation of the selfhood. Too much with-out the world and with-out the self, the sublime in Hopkins is balanced out in the more restrained cosmos of beauty. While Lichtmann's argument that Hopkins feels he has to refute the "Romantic and ultimately solipsistic 
view" (175) is correct to a certain degree, it does fail taking into account that the real affects the experience of the sublime as much as the sublime impacts the experience of the real. The capacity of the spirit to linger in the unresolved tension between the two and be "in uncertainties ... without any irritable reaching after fact and reason" (Keats 60) is a distinctive endowment of Romantic poetry. This vitality and absorption of the creative energy in building form Keats termed negative capability. Not only is the final answer postponed, the Romantic poet prefers the verisimilitude of the vision to remain beyond the grasp of total attainment. The tension being invariably present, the poet keeps revisiting the place of the primal vision and keeps acting as his/her own reminder of the interminable path of homecoming.

\section{IV.}

Florian Deleal at twelve years of age for the first time leaves his old home. The journey to a new place of residence is to be undertaken on the country road, familiar and tender to his vigorous heart. Several miles into the journey, Florian discovers a pet bird missing. He left it in the old house, to which he promptly returns. Upon entering of what is now no longer his home, the exact whereabouts of the bird within the house remain dim. Scouring the place for the deserted pet, he is whelmed by the sensation that something of the essence of youth and homeliness is to be left behind by the act of leaving. He finally finds the bird, and settling at last on the country-road again, and "in an agony of homesickness, thus capriciously sprung up within him, he [is] driven quickly away, far into the rural distance, so fondly speculated on, of that favourite country-road" ("The Child in the House" 15). In Florian a shudder of displacement is born. The trembling of the soul which alone can find both suffering and comfort in being far and near to what once seemed so homely and plain and is now distant and strange.

A similar double bind of displacement expressed by Pater found voice in Hopkins' constant geographical shifts and the shifts he yearned for in his poetical mind and were at times hard if not impossible to come by. When he moved to Dublin, the oppressive joylessness of what had once in the waning days of the $18^{\text {th }}$ century been a city of vibrant and renewing energy sadly affected him. The daily preoccupations of teaching likewise took a shattering toll on Hopkins' fragile and declining health. In a letter to Bridges, he provides more than mere hints about the severity of crisis:

I must write something, though not so much as I have to say. The long delay was due to work, worry, and languishment of body and mind-which must be and will be ... I think that my fits of sadness, though they do not affect my 
judgment, resemble madness. Change is the only relief, and that I can seldom get ... I have after long silence written two sonnets, which I am touching: if ever anything was written in blood one of these was. (216-219)

Change would be the sweet relief, but the boundless maze of daily routine relentlessly bogs him down. A sonnet "written in blood" belongs to a group of sonnets called "The Sonnets of Desolation" or "Terrible Sonnets"; which sonnet exactly Hopkins has in mind is not possible to establish. The overarching theme of the "Terrible Sonnets" bares a heavy-handed burden of anguish descending upon Hopkins in a growing and preponderant isolation and dejection he has to endure in Ireland. In one of the sonnets he writes that "in Ireland now" he is "at a third / Remove" ("To Seem the Stranger" 9-10). The first remove probably alludes to what had initially been a period of acute estrangement from his family due to his conversion to Catholicism, a relationship that had with time become less pernicious, but with a wrinkle of estrangement never wholly smoothed out; the second remove he may have felt in relation to his countrymen who were predominantly devoted Anglicans, while the third remove gives voice to a sharp pang of being stationed in a country whose disloyalty to England is proudly flaunted. His voice "heard unheeded" (14), silence wields the reign of dispirited sameness over the otherwise quickened and subtle movements of Hopkins' mind; it leaves him "a lonely began" (14). The wheel of exclusion is complete:

To seem the stranger lies my lot, my life

Among strangers. Father and mother dear,

Brothers and sisters are in Christ not near

And he my peace/my parting, sword and strife. (1-4)

A poet of imaginative prowess met with sheer formlessness of the natural cosmos, although ultimately defeated and shrunk by the overwhelming gleam of his/her own visionary incandescence, bridges forth from the arranged entities of ordered entropies to the singular and self-contained yet rhyming entropies, where nothing is "so pregnant and straightforward to the truth as simple yes and is" ("Parmenides" 127). Hopkins learns that the desire for the order of affirmation could sap the poetic self of its sprung language. In "Dejection: An Ode," Coleridge lends voice to a very poignant analogy to the type of grief Hopkins feels in proportion to his overly methodical existence:

A grief without a pang, void, dark, and drear,

A stifled, drowsy, unimpassioned grief,

Which finds no natural outlet, no relief,

In word, or sigh, or tear- (21-24) 
The final consummation of dejection occurs when a poet finds the moments previously taking the "soul abroad" and making "it move and live" (18-20) beyond recall. Steep highs that once were at hand presently stand supplanted by the mind intent upon recreating the conditions for the self-edification of the soul. Hopkins' conscious perception that tempestuous monotony is what he righteously owes allegiance to flames the wilting embers of imagination, impelling him towards a dolent observation that the "mind has mountains, cliffs of fall / Frightful, sheer, no-man fathomed" ("No Worst" 9-10). So umbrous are those plunging slopes that none but those touching the lofty ridges and the castigating shadow of the falling could appreciate the mass of lost content in such a downfall. Joy being buried, it is only the assembled gravity of the flux which can halt the slumberous symmetry of the simple yes and is of the artificially-construed order where the poet not being afforded a ground for agonistic strife with nature ineluctably de-natures nature of its poetic and dreadful dynamism. Hopkins unlike Pater cannot renounce the regulative absolutism of form; although Pater is gingerly dancing between faith and the intervallary motions of the mind, he knows a teeming thought plucks its rhymes of things alike and things unlike beyond the hold of the unilateral real. This bargain Hopkins' pious mind dissents from pursuing. Mortal beauty is too perilous, "does set danc- / Ing blood" ("To What Serves Mortal Beauty 1-2); he aspires to "God's better beauty, grace" (14). Even God's beauty, however, is mortally expressed; if the conception of deity lies in its inimitable presence, a poet can resign to silence or a dying coal of what once appeared a towering vision. An alternative is to strive to strive towards the inexpressible, not to construe a definitive version of deity but find joy in that which is un-speakable or beyond the false clarity of immediate expression. Hopkins lies "wrestling with (my God!) my God" ("Carrion Comfort"14); his is a highly personal struggle with language and rhymes - irregular and mirroring God's solitary and ever defying inscape.

Formal disparities between Pater and Hopkins are irrefutable. Pater discerns in Christianity the inestimable value as the building block of a "perfect culture" (“Coleridge's Writings" 449); rather than "craving for objects of belief" (449), he is captivated by the religion of "transcendental disinterestedness" (450) as one of the dominant inflections in art's indelible chants. Faith instituted and roped by doctrinal fixations he cannot bring himself to regard as the bulwark "against the stupidity which is dead to the substance, against the vulgarity which is dead to the form" ("Postscript" 220). The first principle of such defence he unearths in the Romantic intuition which in agreement with Stendhal he acclaims as the fundamental substance of all great art and the guardian of the uncanny within the beautiful. Pater realizes very early that some-thing receives holiness not by virtue of its being revered by Gods; holiness is some-thing which even in Gods invokes reverence. His reasoning leads us to the division of the life-affirming force of the 
boly as opposed to the more religious form of the sacred. Hopkins, naturally, as a priest overturns this balance - the holy is enclosed in the sacred. In poetry, however, the temptations of having the voice of single-mindedness prove multitudinous. At the forefront of his writings is a somewhat mystical swoon directed to secure the salvation of his soul, with the fear of losing his poetic vitality having no smaller outreach. He writes of the first time he saw the Northern Lights:

My eye was caught by the beams of light and dark very like the crown of horny rays the sun makes behind a cloud ... This busy working of nature wholly independent of the earth and seeming to go on in a strain of time not reckoned by our reckoning of days and ears but simpler and as if correcting the preoccupation of the world by being preoccupied with and appealing to and dated to the day of judgment was like a new witness to God and filled me with delightful fear. (Journal 200)

The flares offer a spectacle of the self-governing authority while the earth seems insufficient with the gyres of temporality circumscribing its essential features. The image of the blazing sky is a carnivalesque mockery of a poet's inevitable inadequacy to subdue a nature's grandiose demeanour. Delightful fear is a trope of the balancing ratio between the realm of artistic alacrity and pious devotion. Undue fervor of any form may capsize the delightful fear of uncertainty, for the flare burns, cannot be presumed and, in consequence, contained. In contrast, should the primary intent become the containment of the light, a darkening commotion ensues, in which case delightful fear is overrun by prostrating despair.

The passage at least in its theme coincides with some of the famous pastoral elegies for the self in the language. Hopkins knows that "the dedications of priest and poet [are] too much alike to exist easily in one person" (Martin 165). Starting "with form" ("Postscript" 218), Hopkins the priest espouses the Word becoming incarnate as the point of origin. The Light he sees as of God, for God, and through God, is made to replenish an always impatient source of human belief. Hopkins the poet celebrates the Light and its form as the primal aim. The aim flourishes into a playground of words and ideas; in Pater's words, into an inlet for "the rudeness of [a poet's] strength" (>Pater, "Postscript" 219). Strangeness perforates the regular shape of life. The split of the holy and the sacred within the self, as conceived by the poetic genius, whose contemplative character, in Hopkins as much aesthetic as it is religious, renders possible the union of beauty and strangeness. The yearning for the authentic language of unity Pater and Hopkins share, yet it is the metaphysical ambition which Hopkins at the same time necessarily traces in it and cannot forego that motivates and confirms the formally philosophical if not visionary rift between the two poetic souls. 


\section{REFERENCES}

Barrett, E. Boyd. The Jesuit Enigma. New York: Boni \& Liveright, 1927. Print. Blake, William. "Milton: A Poem in 2 Books, Book the Second." The Complete Poetry and Prose of William Blake. Ed. David V. Erdman. Berkeley: University of California Press. 129-144.

Bloom, Harold. Introduction: The Crystal Man. Selected Writings of Walter Pater. By Walter Pater. New York: Signet, 1974. vii-xxxi. Print.

Coleridge, Samuel Taylor. "Dejection: An Ode.” The Major Works. Ed. H. J. Jackson. New York: Oxford University Press, 2008. 114. Print.

Crane, Hart. "To Brooklyn Bridge." Complete Poems of Hart Crane. Ed. Marc Simon. New York: Liveright, 2001. 43-44. Print.

Downes, David Anthony. Victorian Portraits: Hopkins and Pater. New York: Bookman Associates, 1965. Print.

Higgins, Lesley. "Essaying 'W. H. Pater Esq.': New Perspectives on the Tutor/ Student Relationship Between Pater and Hopkins." Pater in the 1990s. Eds. Laurel Brake and Ian Small. Greensboro: ELT Press, 1991. PDF.

Higgins, Lesley. "A 'Thousand Solaces' For the Modern Spirit: Walter Pater's Religious Discourse." Victorian Religious Discourse: New Directions in Criticism. Ed. Jude V. Nixon. New York: Palgrave Macmillan, 2004. 189-204. Print.

Hopkins, Gerard Manley. "Carrion Comfort." The Major Works. Ed. Catherine Phillips. New York: Oxford University Press, 2009. 168. Print.

Hopkins, Gerard Manley. "God's Grandeur." The Major Works. Ed. Catherine Phillips. New York: Oxford University Press, 2009. 128. Print.

Hopkins, Gerard Manley. "Journal (1866-1875)." The Journals and Papers of Gerard Manley Hopkins. Eds. Humphry House and Graham Storey. New York: Oxford University Press, 1959. 131-265. Print.

Hopkins, Gerard Manley. "Letter III: 5-10 Oct. 1878." The Correspondence of Gerard Manley Hopkins and Richard Watson Dixon. Ed. Claude Colleer Abbott. London: Oxford University Press, 1955. 12-16. Print.

Hopkins, Gerard Manley. “Letter LXXXVI: 12 Feb. 1879.” Further Letters of Gerard Manley Hopkins, Including his Correspondence with Coventry Patmore. Ed. Claude Colleer Abbott. 2nd ed. London: Oxford University Press, 1970. 151-153. Print. Hopkins, Gerard Manley. "Letter CXX: 10-13 Jul. 1863." Further Letters of Gerard Manley Hopkins, Including his Correspondence with Coventry Patmore. Ed. Claude Colleer Abbott. 2nd ed. London: Oxford University Press, 1970. 199-202. Print. Hopkins, Gerard Manley. “Letter CXXXVI: 22 May-18 Jun. 1880.” Further Letters of Gerard Manley Hopkins, Including his Correspondence with Coventry Patmore. Ed. Claude Colleer Abbott. 2nd ed. London: Oxford University Press, 1970. 244-246. Print. 
Hopkins, Gerard Manley. "Letter CX: 24-25 Oct. 1883.” The Letters of Gerard Manley Hopkins to Robert Bridges. Ed. Claude Golleer Abbott. London: Oxford University Press, 1935. 186-189. Print.

Hopkins, Gerard Manley. “Letter CXXIX: 17-29 May. 1885.” The Letters of Gerard Manley Hopkins to Robert Bridges. Ed. Claude Golleer Abbott. London: Oxford University Press, 1935. 216-220. Print.

Hopkins, Gerard Manley. "Notes on Greek Philosophy." Collected Works of Gerard Manley Hopkins, Volume IV: Oxford Essays and Notes. Ed. Lesley Higgins. New York: Oxford University Press, 2006. 304-322. Print.

Hopkins, Gerard Manley. "No Worst." The Major Works. Ed. Catherine Phillips. New York: Oxford University Press, 2009. 167. Print.

Hopkins, Gerard Manley. "On the Signs of Health and Decay in the Arts." The Journals and Papers of Gerard Manley Hopkins. Eds. Humphry House and Graham Storey. New York: Oxford University Press, 1959. 74-79. Print.

Hopkins, Gerard Manley. "The Origin of Our Moral Ideas." The Journals and Papers of Gerard Manley Hopkins. Eds. Humphry House and Graham Storey. New York: Oxford University Press, 1959. 80-83. Print.

Hopkins, Gerard Manley. "Parmenides." The Journals and Papers of Gerard Manley Hopkins. Eds. Humphry House and Graham Storey. New York: Oxford University Press, 1959. 127-130. Print.

Hopkins, Gerard Manley. "Poetic Diction." The Journals and Papers of Gerard Manley Hopkins. Eds. Humphry House and Graham Storey. New York: Oxford University Press, 1959. 84-85. Print.

Hopkins, Gerard Manley. "The Probable Future of Metaphysics." The Journals and Papers of Gerard Manley Hopkins. Eds. Humphry House and Graham Storey. New York: Oxford University Press, 1959. 118-121. Print.

Hopkins, Gerard Manley. "To Seem the Stranger." The Major Works. Ed. Catherine Phillips. New York: Oxford University Press, 2009. 166. Print.

Hopkins, Gerard Manley. "A Trio of Triolets." The Major Works. Ed. Catherine Phillips. New York: Oxford University Press, 2009. 157-158. Print.

Hopkins, Gerard Manley. "To What Serves Mortal Beauty." The Major Works. Ed. Catherine Phillips. New York: Oxford University Press, 2009. 167. Print.

Iser, Wolfgang, Walter Pater. The Aesthetic Moment. Translated by David Henry Wilson. New York, Cambridge University Press, 2011. Print.

Keats, John. "Letter to George and Tom Keats, 22 Dec. 1818." Selected Letters of John Keats. Ed. Grant F. Scott. Cambridge: Harvard University Press. 59-61. Print.

Lichtmann, Maria R. The Contemplative Poetry of Gerard Manley Hopkins. New Jersey: Princeton University Press, 1989. Print.

Mariani, Paul. Gerard Manley Hopkins. New York: Viking/Penguin, 2008. Print. 
Martin, Robert Bernard. Gerard Manley Hopkins: A Very Private Life. London, Flamingo, 1991. Print.

Miller, J. Hillis. The Disappearance of God: Five Nineteenth-Century Writers. Cambridge: The Belknap Press of Harvard University Press, 1963.

Millhauser, Milton. "Walter Pater and the Flux." The Journal of Aesthetics and Art Criticism 11.3 (1953): 214-23. JSTOR. Web.

Monsman, Gerald C. "Old Mortality at Oxford." Studies in Philology 67.3 (1970): 359-89. JSTOR. Web.

Monsman, Gerald C. Walter Pater. Boston: Twayne Publishers, 1977. Print.

O'Keefe, Tim. Epicurianism. Durham: Acumen, 2010. Print.

Pater, Walter. “The Child in the House." Selected Writings of Walter Pater. Ed. Harold Bloom. New York: Signet, 1974.1-16. Print.

Pater, Walter. "Coleridge's Writings." English Critical Essays (Nineteenth Century). Ed. Edmund D. Jones. London: Oxford University Press, 1956. 421-457. Print.

Pater, Walter. Marius the Epicurean: His Sensations and Ideas. New York: Cosimo Classics, 2005. Print.

Pater, Walter. "A Novel by Mr. Oscar Wilde." Selected Writings of Walter Pater. Ed. Harold Bloom. New York: Signet, 1974. 263-266. Print.

Pater, Walter. "Postscript (Romanticism)." Selected Writings of Walter Pater. Ed. Harold Bloom. New York: Signet, 1974. 208-223. Print.

Pater, Walter. Studies in the History of the Renaissance. Ed. Matthew Beaumont. New York: Oxford University Press, 2010. Print.

Pater, Walter. "Wordsworth." Selected Writings of Walter Pater. Ed. Harold Bloom. New York: Signet, 1974. 125-142. Print.

Ruskin, John. The Elements of Drawing. New York: John Wiley \& Son, 1872. PDF. Ruskin, John. Modern Painters III. London: Smith, Elder, 1872. PDF.

Saville, Julia F. A Queer Chivalry: The Homoerotic Asceticism of Gerard Manley Hopkins. Charlottesville and London: University Press of Virginia, 2000. Print.

Shuter, William F. Rereading Walter Pater. New York: Cambridge University Press, 2005. Print.

Stevens, Wallace. "The Auroras of Autumn." The Collected Poems of Wallace Stevens. New York: Vintage, 1990. 411-421. Print.

Stevens, Wallace. "The Place of the Solitaries." The Collected Poems of Wallace Stevens. New York: Vintage, 1990. 60. Print.

White, Norman. Hopkins: A Literary Biograpy. New York: Oxford University Press, 1992. Print.

Willems, Brian. Hopkins and Heidegger. London and New York: Continuum International Publishing Group, 2009. Print. 
Wordsworth, William. "Ode: Intimations on Immortality." Selected Poetry. Eds. Stephen Gill and Duncan Wu. New York: Oxford University Press, 2008. 140-146. Print.

Wright, Thomas. The Life of Walter Pater, vol. I. London: Everett \& Co., 1907. Print.

Mirko Starčević

Ljubljana

mirko.starcevic@gmail.com

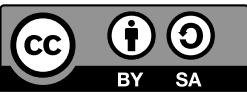

\section{Gerard Manley Hopkins in Walter Pater: Labirinti minljivosti}

Minljivost, ki gradi jedrni tok življenja, je močno zaznamovala ustvarjanja Gerarda Manleyja Hopkinsa in Walterja Paterja. Permanentno nedoločena prisotnost spremenljivega je oba ustvarjalca soočila s temno in nespoznavno podobo smrti in jima razprla vprašanje o vlogi umetnosti v nezaustavljivem razkroju, ki vlada življenju. Pater sprejme tok spremenljivosti kot ključni delež razodetja samolastnega umetniškega izkustva. V umetnosti moč iskrivega razkrivanja dopolnjuje v negotovo usodnost pokopano konstitucijo življenjskega bistva. Hopkins kot duhovnik v umetnosti zlasti v teoretičnem oziru spozna le približek brezčasne veličine božjega obličja, a njegova poezija izpričuje drugačno zgodbo. Pesniška podoba Hopkinsu predstavlja izpostavljeno individualnost romantičnega duha, ki ga je Pater dojemal kot sorodnost tujosti in lepega. $V$ času Hopkinsovega študija na Oxfordu Pater ni bil le mentor mladega pesnika. Mnogo časa sta preživela v pogovoru, prevprašujoč temeljna določila umetniškega ustvarjanja. Pater je na Hopkinsa torej močno vplival in doprinesel mnogo k vzgoji njegovega pesniškega srca. Sledi tega odnosa ne najdejo poti v Hopkinsova verska premišljevanja; svojo navzočnost razkrivajo, čeprav zelo prikrito, na posameznih ravneh Hopkinsovih pesniških hrepenenj.

Ključne besede: Hopkins, Pater, romantika, spremenljivost, lepota 